\title{
PERAN DOSEN DALAM MENGEMBANGKAN KARAKTER MANDIRI PADA MASHASISWA
}

\author{
Dada Suhaida ${ }^{1}$, Idham Azwar ${ }^{2}$ \\ ${ }^{1,2}$ Program Studi Pendidikan Pancasila dan Kewarganegaraan \\ Fakultas Ilmu Pendidikan dan Pengetahuan Sosial IKIP PGRI Pontianak \\ Jalan Ampera Nomor 88 Pontianak - 78116, Telepon (0561) 748219 Fax. (0561) 589855 \\ ${ }^{1}$ Alamat e-mail: civic.link@yahoo.com
}

\begin{abstract}
Abstrak
Penelitian ini untuk memfokuskan pada Peran Dosen dalam Mengembangkan Karakter Mandiri pada Mahasiswa. Masalah umum penelitian tentang "Peran Dosen Prodi PPKn dalam Mengembangkan Karakter Mandiri pada Mahasiswa". Masalah Khusus yakni; 1) Bagaimana dosen menyadari tugasnya dan meningkatkan kemampuannya dalam mengembangkan karakter mandiri pada mahasiswa, 2) bagaimana peran dosen dalam memberikan kontribusi untuk mengembangkan karakter mandiri mahasiswa. Subyek penelitian 2 orang dosen Prodi PPKn dan 5 orang mahasiswa PPKn. Tujuan dalam penelitian ini; 1) Mengetahui dosen menyadari tugasnya dan meningkatkan kemampuannya dalam mengembangkan karakter. Metodologi penelitian deskriptif kualitatif dengan teknik dan alat pengumpul data yakni; observasi dengan alat pedoman observasi, wawancara dengan daftar pertanyaan, studi dokumentasi dengan foto dan kartu hasil studi. Teknik analisa data reduksi data, display/penyajian data, dan verifikasi data. Secara umum hasil penelitian mengungkapkan bahwa dosen sudah seoptimal mungkin dalam berupaya mengembangkan karakter mandiri. Secara khusus hasil penelitian menginformasikan bahwa, dosen sudah menyadari tugas dan meningkatkan kemampuan dalam mengembangkan karakter mandiri mahasiswa, dan peran dosen dalam memberikan kontribusi untuk mengembangkan karakter mandiri mahasiswa cukup besar.
\end{abstract}

Kata Kunci: Peran Dosen, Karakter Mandiri.

\begin{abstract}
This research is focused on the role of lecturer in developing students' independent character in university. The general problem of this research that entitled "The Role of Lecturer in developing students' independent character of PPKn Study Program". The particular issue of this research are : 1) How does the lecturer aware about their duty and improveing their ability in developing students'indepedent character. 2) what is the lecturer roles in contributing students' independent character development. The sample of this research was taken from two lecturers and five students of PPKn study program. The purpose of conducting this research: to acknowlage the lecturer awareness about their duty and improving their ability in developing students' independent character. The metodology that used in this research was descriptive qualitative with techniques and data collection tools such as: observation with observation guidance, interview with question list, documentation study with picture and study report card. Data analysis techniques for data reduction, display/data presentation dan data verification. Generally, the results revealed that lecturer have been as optimal as possible in developing students' independent character. In particular, the result of this research informed that lecturer realized about their duty and improveing their ability in developing students'indepedent character and the roles of lecturer in contributing students' independent character development was great inough.
\end{abstract}

Keywords: the role of lecturer, independent character. 


\section{PENDAHULUAN}

Pada masa sekarang ini para mahasiswa kurang sekali memiliki karakter mandiri dalam mengikuti proses perkuliahan. masih banyak mahasiswa terlihat tidak sungguh-sungguh saat mengikuti proses belajar mengajar, hal tersebut dapat terlihat dari aktivitas mahasiswa ketika sedang mengikuti perkuliahan, yang sebagian besar mahasiswa lebih pasif ketika dosen memberikan materi maupun tugas laporan dalam bentuk makalah yang akan didiskusikan. Ada juga mahasiswa yang jarang hadir saat jam perkuliahan. Kepasifan belajar mahasiswa dapat diamati dari sikap mereka yang lebih cenderung diam ketika dosen memberikan waktu tanya jawab, kemudian mahasiswa lebih memilih diam dan enggan memberikan komentar ataupun tanggapan ketika ada tugas persentasi laporan makalah yang diberikan oleh dosen. Terlihat dari beberapa aktivitas perkuliahan mahasiwa yang aktif dan kreatif hanya sebagian kecil dan diketahui bahwa mahasiswanya yang itu-itu saja. Fenomena ini masih saja terus terjadi di lingkungan mahasiswa program studi Pendidikan Pancasila dan Kewarganegaraan (PPKn).

Mencermati kasus ketidakmandirian mahasiswa di lingkungan Program Studi PPKn dalam mengikuti perkuliahan dapat disebabkan oleh kebiasaan malas untuk mengembangkan Caracter disposition dan ingin serba mudah. Dapat diartikan, mahasiswa yang bersangkutan hanya ingin memproleh hasil yang bagus tetapi tidak mau belajar serta mengembangkan dirinya. Apabila hal-hal seperti ini terus saja dibiarkan akan dapat menciptakan budaya malas, manja, dan tidak mau bekerja keras untuk mengembangkan karakter mandiri mahasiswa. Calon-calon sarjana pendidik yang bemental tempe akan tumbuh subur di masyarakat. Untuk hal itu, pihak fakultas maupun para pendidik di lingkungan Prodi PPKn harus bersungguh-sungguh mengupayakan kesadaran mahasiswa untuk mengembangkan karakter mandiri mahasiswa dalam mengikuti proses perkuliahan.

Melihat karakter ketidakmandirian mahasiswa tersesbut, peneliti sangat menyadari bahwa upaya pendidikan mengembangkan beberapa karakter salah 
satunya karakter mandiri mahasiswa di Fakultas Pendidikan Ilmu Sosial pada dasarnya tidak semata-mata dibebankan kepada dosen PPKn saja, akan tetapi kepada seluruh dosen. Para seluruh dosen tidak hanya saja dosen PPKn perlu menyadari peran penting dalam menjalankan tugas dan fungsi pokok dosen di lingkungan perguruan tinggi dengan didukung oleh setiap elemen perguruan tinggi. Artinya, seorang dosen adalah seorang pendidik, kata pendidik menjadi kunci di perguruang tinggi karena seorang dosen tidak hanya memberikan ilmu pengetahuan maupun keterampilan, tetapi lebih dari pada itu seorang dosen juga wajib memberikan teladan dan motivasi untuk mahasiswanya. Sehingga mahasiswa dapat tumbuh dan berkembang menjadi individu yang baik dan seimbang secara akademik dan mental (hardskills dan soft skills).

Sebagai pendidik dosen memiliki tugas pokok yang dikenal dengan Tri Dharma Perguruan Tinggi, yakni kegiatan pendidikan, penelitian, pengabdian kepada masyarakat. Salah satu tugas dari Tri Dharma yaitu bahwa, pendidikan mengisyaratkan kepada dosen agar tidak saja mengajarkan materi, selain daripada itu dosen juga harus berupaya mengembangkan nilai-nilai luhur agar terbentuk karakter yang mandiri kepada para mahasiswa, karena karakter yang mandiri merupakan salah satu faktor yang sangat menentukan keberhasilan mahasiswa di masa depan.

Pengembangan karakter mandiri yang dilakukan oleh dosen kepada para mahasiswa memerlukan pemahaman, keterampilan, dan kompetensi mengenai karakter mandiri itu sendiri. Tetapi yang lebih penting, bagaimana seorang dosen mampu berperan serta menularkan dalam dirinya karakter-karakter luhur dan mulia yang bisa dicontoh serta diteladani oleh mahasiswanya.

Karakter luhur yang seperti apa yang harus dimiliki oleh seorang dosen? Karakter luhur dosen yang kiranya dapat beperan besar untuk menanamkan kesadaran mahasiswanya untuk terus belajar mengembangkan pengetahuannya, dan menjadi peribadi mandiri yang mampu mengembangkan keterampilan, berani mengemukakan pendapat, aktif dalam setiap proses perkuliahan. Dosen yang memiliki karakter luhur dapat dicermati dengan ciri-ciri sebagai berikut: memiliki kompeten dalam bidang keilmuawannya, cerdas, memiliki komitmen, konsisten, 
sederhana, memiliki kemampuan berkomunikasi, melayani dengan penuh tanggungjawab, selalu menjaga kehormatan dirinya, dan dapat menjadi suri teladan bagi mahasiswanya.

Pentingnya pendidikan karakter tertuang dalam Undang-undang Nomor 20

Tahun 2003 tentang Sistem Pendidikan Nasional dalam pasal 3 bahwa:

"Pendidikan nasional berfungsi mengembangkan kemampuan dan membentuk watak serta peradaban bangsa yang bermartabat dalam rangka mencerdaskan kehidupan bangsa, bertujuan untuk berkembangnya potensi peserta didik agar menjadi manusia yang beriman dan bertaqwa kepada Tuham YME, berahlak muli, sehat, berilmu, cakap kreatif mandiri, dan menjadi warga negara yang demokratis serta bertanggung jawab".

Mengacu pada pernyataan tersebut, tergambar bahwa tujuan pendidikan nasional secara utuh adalah pengembangan karakter peserta didik. Selain itu seorang dosen juga harus memiliki kemampuan mengelola proses belajar mengajar. Subroto, (2002: 179) menyatakan bahwa kemampuan mengelola proses belajar mengajar adalah kesanggupan atau kecakapan para dosen dalam menciptakan suasana komunikasi yang edukatif antara dosesn dan peserta didiknya, yang mencakup segi kognitif, afektif dan psikomotor, sebagai upaya mempelajari sesuatu berdasarkan perencanaan sampai dengan tahap evaluasi dan tindak lanjut agar tercapai tujuan pengajaran.

Sejalan dengan penelitian yang dilakukan oleh Bali (2013: 1) yang berjudul "Peran Dosen dalam Mengembangkan Karakter Mahasiswa", dalam penelitiannya Bali menyatakan, bahwa peran dosen dalam membentuk karakter mahasiswa merrupakan aspek yang sangat penting. Dosen tidak hanya mengajar tetapi juga mendidik, membimbing, melatih, dan juga memberikan evaluasi atau penilaian terhadap berabagai pembelajaran di kelas. Di sini dosen merupakan salah satu unsur utama selain mahasiswa, dan masyarakat akademik di perguruan tinggi. Tugas pokok dosen adalah melaksanakan Tri Dharma Perguruan Tinggi, yaitu kegiatan pendidikan, penelitian, dan pengabdian kepada masyarakat. Kegiatan-kegiatan ini merupakan inti dari semua aktivitas dosen dalam masyarakat akademik perguruan tinggi. Selanjutnya Bali (2013: 10) menekankan, bahwa dosen yang berperan dalam pendidikan karakter adalah dosen yang mampu 
melihat profesinya sebagai panggilan jiwa. Ia melaksanakan berbagai tugasnya yang terangkum dalam tridharma perguruan tinggi. Di sisi lain, seorang dosen sebagaiamana seorang guru, merupakan aktor utama dalam pembelajaran. Peran dosen dalam keberhasilan internalisasi pendidikan karakter kepada para mahasiswanya adalah kunci utama.

Faktor lain adalah seperti kurikulum, budaya, kegiatan-kegiatan spontan, hanya merupakan pendukung bagi dosen. Bali melanjutkan, bahwa pendidikan karakter di perguruan tinggi harus dilakukan melalui pembiasaan kehidupan keseharin di kampus, sehingga menjadi budaya kampus. Bentuk nyata tampak dalam kegiatan mahasiswa seperti olahraga, karya tulis, kesenian, dan sebagainya. Strategi lain adalah mewujudkan budaya akademik yang merupakan manifistasi dari nilai-nilai luhur total dalam budaya akademik. Wujudnya dalam bentuk kegiatan kurikuler, kokurikuler, atau kegiatan mahasiswa yang berbasis pada bidang profesi yang dipelajari, dan ekstrakurikuler. Secara lengkap Bali (2013) menyimpulkan, bahwa peran dosen dalam menginternalisasikan nilai-nilai luhur atau pendidikan karakter di perguruan tinggi adalah menetapkan tujuan, sasaran, dang target yang jelas dan konkret: perlu kerja sama semua pihak antara perguruan tinggi, orang tua mahasiswa, dan juga dosen: manyadarkan pada smeua dosen akan peran penting dan tanggungjawab dalam keberhasilan melaksanakan dan mencapai tujuan pendidikan karakter; kesadaran para dosen akan perlunya hidden curriculum merupakan instrument penting dalam pengembangan karakter mahasiswa; keteladanan dosen dalam pendidikan karakter. Keteladanan menjadi komunikasi yang efektif dalam mengembangkan nilai-nilai luhur dalam diri mahasiswa; dosen perlu menekankan daya kritis pada mahasiswa; membangun budaya perguruan tinggi yang menghargai nilai-nilai luhur atau karakter bangsa; dan melakukan pembiasaan dalam kehidupan sehari-hari di kampus kemudian membentuk budaya kampus.

Jelas kiranya dari pembahasan di atas diketahui bahwa pendidikan karakter mandiri merupakan faktor yang penting juga dan tidak bisa dipisahkan dari kehidupan seseorang, baik dalam keluarga, masyarakat maupun bangsa. Seorang dosen yang memiliki karakter luhur seperti yang disebutkan di atas dapat 
dijadikan sebagai landasan untuk melakukan dan mengoptimalkan perannya dalam melakukan proses pembelajaran dalam mengembangkan karakter mandiri pada mahasiswanya. Oleh karena itu peneliti secara khusus menekankan bahwa pentingnya menganalisis tentang "peran dosen dalam mengembangkan karakter mandiri mahasiswanya dalam proses pembelajaran”.

\section{METODE}

Metode yang digunakan dalam penelitian ini adalah metode deskriptif dengan pendekatan kualitatif. Alasan metode dan pendekatan penelitian ini dipilih karena, masalah yang ingin diketahui menyangkut masalah yang sedang berkembang dalam proses pembelajaran Pendidikan Pancasila dan Kewarganegaraan. Diharapkan dengan metode diskriptif dan pendekatan kualitatif atas fenomena di lapangan dapat diinterprestasikan makna dan isinya lebih mendalam. Metode penelitian deskriptif adalah satu metode penelitian yang banyak digunakan pada penelitian yang bertujuan menjelaskan suatu kejadian. Seperti yang dikemukakan oleh Sugiyono (2011: 32), "Penelitian deskriptif adalah sebuah penelitian yang bertujuan untuk memberikan atau menjabarkan suatu keadaan atau fenomena yang terjadi saat ini dengan menggunakan prosedur ilmiah untuk menjawab masalah secara aktual”. Selanjutnya Sukmadinata (2006: 72) menyatakan,

"Metode penelitian deskriptif adalah metode yang berusaha mendeskripskan, menginterprestasikan sesuatu, misalnya kondisi atau hubungan yang ada, pendapat yang berkembang, proses yang sedang berlangsung, akibat atau efek yang terjadi atau tentang kecenderungan yang sedang berlangsung".

Dari kedua pengertian di atas, dapat dikatakan bahwa metode penelitian deskriptif adalah sebuah metode yang digunakan untuk mendeskripsikan pendapat yang berkembang, dengan menggunakan prosedur ilmiah untuk menjawab masalah secara aktual. Dengan demikian penulis beranggapan bahwa metode penelitian deskriptif sesuai dengan penelitin yang dilakukan oleh penulis. Karena dalam penelitian ini penulis berusaha mendeskripsikan sebuah masalah atau 
fenomena yang terdapat pada "Peran Dosen dalam mengembangkan Karakter Mandiri pada Mahasiswa”.

Pendekatan dalam penelitian ini adalah kualitatif atau naturalistik. Penelitian kualitatif betolok dari filsafat kontruktivisme yang berasumsi bahwa, kenyataan itu berdemensi jamak. Interaktif dan suatu pertukaran pengalaman sosial yang diinterprestasikan oleh individu-individu. Penelitian kualitatif ditunjukkan untuk memahami fenomena-fenomena sosial dari sudut pandang prespektif pastisipan. Partisipan adalah orang-orang yang diajak berwawancara, diobservasi, diminta memberikan data, pendapat, pemikiran, serta persepsinya (Sukmadinata, 2006:94). Disamping itu, penelitian kulaitatif menekankan pada faktor peneliti sebagai alat utama. Penelitian inipun memperhatikan pula metode yang digunakan agar hasilnya sesuai dengan yang diharapkan. Dengan demikian, pendekatan kualitatif adalah suatu proses penelitian dan pemahaman yang berdasarkan pada metodologi yang menyelidiki suatu fenomena sosial dan masalah manusia. Peneliti membuat suatu gambaran yang komplek, meneliti katakata, laporan terinci dari pandangan subjek penelitian dna mendefinisikan penelitian sebagai berikut:

"Qualitative research is an inquiry process of understanding based on distinct methodological traditions of inquiry that explore a social or human problem. The researcher builds a complex, holistic picture, analyeses word, report detailed views of informants, and conducts the study in a natural setting".

Dengan demikian dapat diartikan bahwa, penelitian kualitatif adalah proses penelitian tentang pemahaman berdasarkan tradisi metodologi penelitian tertentu dengan cara menyelediki masalah sosial atau manusia. Peneliti membuat gambaran kompleks dan holistik, menganalisis kata-kata melaporkan pandanganpandangan para pasrtisipan secara rinci dan melakykan penelitian dalam situasi alamiah. Jadi dapat dirumuskan karakteristik utama yang menjadi perhatian dalam penelitian kualittaif ini adalah, kepedulian tarhadap "makna". Dalam hal ini penelitian kualitatif ini tidak perduli terhadap persamaan dari objek penelitian melainkan sebaliknya mengungkap pandangan tentang kehidupan orang yang 
berbeda-beda. Dengan demikian metodologi yang digunakan dalam penelitian ini adalah metodologi diskriptif kualitatif.

Subjek dalam penelitian ini, yakni 2 orang dosen di lingkungan Prodi PPKn, dan 5 orang mahasiswa Prodi PPKn, serta peneliti sendiri sebagai instrument dalam penelitian ini.

Teknik dan alat pengumpul data yang digunakan dalam penelitian ini adalah, teknik observasi langsung dengan cara mengumpulkan data yang dilakukan melalui pengamatan dan pencatatan gejala-gejala yang tampak pada objek penelitian yang menjadi pelaksaannya langsung di tempat dimana suatu kejadian, keadaan atau situasi sedang terjadi (Nawawi, 2007: 94). Teknik yang digunakan dalam penelitian ini adalah komunikasi, teknik observasi dan teknik dokumentasi. Teknik komunikasi langsung yang menggunakan alat pedoman wawancara untuk menjaring data, dengan cara mengumpulkan informasiinformasi yang mengharuskan peneliti mengadakan kontak langsung secara lisan ataupun tatap muka (face to face) dengan sumber data, baik dalam situasi yang sengaja dibuat untuk keperluan tersebut guna memperoleh data ataupun informasi mengenai "peran dosen dalam mengembangkan sikap mandiri mahasiswa di lingkungan prodi PPKn". Selanjutnya teknik observasi yakni dengan menggunakan alat panduan observasi untuk menjaring data dengan melihat gejalagejala atau fenomena-fenomena bagaimana "peran dosen dalam memgembangkan karakter mandiri mahasiswa di lingkungan Prodi PPKn". Sedangkan teknik dokumentasi dilakukan untuk mengumpulkan data berupa foto-foto, hasil belajar mahasiswa berupa kartu rencana studi dan kartu hasil studi guna melihat bagaimana hasil kemandirian belajar mahasiswa di lingkungan Prodi PPKn. Selanjutnya untuk menjawab sub masalah yakni, teknik analiasa data yang digunakan adalah reduksi data, display/penyajian data, dan verifikasi data.

\section{HASIL DAN PEMBAHASAN}

\section{A. Dosen Menyadari Tugasnya dan Meningkatkan Kemampuannya Dalam Mengembangkan Karakter Siswa}


Pengembangan karakter mandiri kepada mahasiswa adalah suatu yang mesti dilakukan secara tepat dan bertanggungjawab oleh dosen yang ada di lingkungan prodi PPKn. Berdasarkan dari temuan di lapangan bahwa, seringkali mahasiswa pada masa kini masih sering melakukan pelanggaran etika, istilah yang biasa disebut dengan moral, ahlak, watak, tabiat, dan karakter. Seringkali mahasiswa melakukan perbuatan atau tindakan yang tidak sesuai dengan etika seperti, kurangnya sikap sopan satun para mahasiswa, berbohong kepada dosen, menyotek tugas dari temannya, bahkan dapat ditemui mahasiswa yang kurang aktif dan tidak percaya diri dalam proses perkuliahan. bahkan ada beberapa kasus yang terjadi di kalangan mahasiswa yang kurang terpuji, yakni seperti mahasiswa yang tidak membuat tugas, mahasiswa yang kurang aktif dalam proses perkuliahan. dari hal tersebut dapat dicermati bahwa fenomena tersebut dilakukan oleh mahasiswa dikarenakan budaya malas dan ingin semuanya berjalan serba mudah dan cepat saja. Apabila hal-hali tersebut dibiarkan bukan tidak mustahil makin banyak mahasiswa yang memiliki karakter yang lemah (tidak mandiri) dikarenakan malas untuk mengembangkan kemampuan dirinya sendiri.

Mencermati kejadian tersebut, penulis menyadari bahwa upaya menguatkan peran dosen dalam meningkatkan karakter mandiri mahasiswa di lingkungan Program Studi PPKn IKIP PGRI Pontianak tidaklah semudah yang dibayangkan, apabila dosen pengasuh mata kuliah tidak didukung juga oleh mahasiswanya. Dalam artian, tugas meningkatkan karakter mandiri mahasiswa untuk lebih mandiri agar aktif dalam proses perkuliahan agar dapat membentuk pribadi yang lebih percaya diri bukanlah semata-mata hanya dibebankan kepada dosen mata kuliah saja, melainkan kepada mahasiswa yang bersangkutan. Namun, sudah sejatinya para dosen (tidak hanya dosen character building) juga perlu menyadari perannya dalam menjalankan tugas serta fungsi pokok sebagai dosen di lingkungan Prodi PPKn dan perguruan tingginya, namun tugas dan fungsi pokok dosen juga harus didukung oleh para tenaga kependidikan, sarana, dan prasarana, serta program kegiatan akademik dan non-akademik. Artinya, seorang dosen sebagai pengajar dan pendidik bahwa dosen tidak hanya mentrasferkan ilmu pengetahuan dan keterampilan saja, namun lebih penting dosen juga mengajarkan 
teladan, motivasi, serta semangat untuk para mahasiswanya. Sehingga diharapkan mahasiswa dapat berkembang sebagai mahasiswa yang mandiri serta percaya diri secara mental dan akademik. Sikap tidak mandirinya beberapa mahasiswa di lingkungan Prodi PPKn merupakan tugas dan tanggungjawab semua dosen Prodi PPKn untuk lebih menanamkan maupun meningkatkan kesadaran bahwa perlu sekali memupuk diri membuang sikap malas dan ingin segala sesuatu bersifat praktis saja. Dosen PPKn juga bertugas memberikan pemahaman bahwa dalam proses perkuliahan sebuah jiwa perjuangan, kesabaran, dan nilai kejujuran sangat penting ditingkatkan.

Berdasarkan hasil observasi dan wawacara, beberapa dosen di lingkungan Prodi PPKn menyatakan bahwa, dosen merasa sudah berusaha seoptimal mungkin dalam memberikan pemahaman kepada beberapa mahasiswa yang masih kurang mandiri dalam melaksanakan proses perkuliahan. bahkan dosen juga tidak segansegan menegur mahasiswa yang kedapatan melakukan pelangaran yang dilakukan selama proses perkuliahan berlangsung, dosen juga tidak segan memarahi maupun memberikan hukuman apabila pelangaran yang dilakukan mahasiswa tidak dapat ditoleren lagi. Misalnya, dosen PPKn mendapati ada beberapa mahasiswa yang menjiplak tugas dari teman yang lain, mahasiswa tidak mengejarkan tugas mandiri ataupun tugas kelompok, dan mahasiswa yang kurang aktif falam perkuliahan. Adapun sanksi yang diberika dosen kepada mahasiswa adalah; dosen mengurangi nilai mahasiswa tersebut, dan dosen juga menasehati agar perbuatan tersebut jangan diulangi kembali. Meskipun menurut narasumber dosen prodi PPKn masih ada dosen di lingkungan Prodi PPKn terkadang kurang komitmen dalam menerapkan aturan kepada mahasiswa yang melakukan pelangaran, sehingga sampai saat ini masih didapati mahasiswa yang tidak merubah karakter dirinya untuk lebih berbuat dan bertindak lebih positif lagi, dan tidak heran masih juga ditemu beberapa mahasiswa yang tidak mengindahkan peringatan dari dosen.

Dari beberapa temuan di lapangan tersebut, dapat disimpulkan sementara bahawa, dosen yang ada di lingkungan Prodi PPKn sudah menyadari tugasnya sebagai tenaga pengajar (dosen) dan memahami fungsi pokok sebagai pendidik yang baik dan seharusnya, dari data observasi dosen di lingkungan Prodi PPKn 
sudah telihat cakap dalam menyampaikan ilmu pengetahuan dan mampu memberikan pemahaman kepada mahasiswa, bahwa pentingnya untuk meningkatkan kemandirian diri dalam menjalani proses perkuliahan. Dosen juga cakap dalam mengambil keputusan berupa teguran dan hukuman secara mandiri bagi mahasiswa yang kedapatan melakukan pelangaran yang disebutkan pada paparan di atas. dapat terlihat bahwa, dedikasi para dosen yang ada di lingkungan Prodi PPKn terhadap profesinya mencerminkan pada sikap pengabdian secara optimal dengan menggunakan pengetahuan dan kecakapan yang dimilikinya. Meskipun demikian, masih ada beberapa dosen yang terkesan masih mengabaikan pelangaran-pelangaran yang diperbuat oleh mahasiswa. Namun hal tersebut tidak terlalu mempengaruhi peran dosen yang lain untuk lebih meningkatkan dirinya dalam mengembangkan karakter mandiri kepada mahasiswa. Salah satu contoh, dosen berperan dalam memberikan keteladanan dalam bentuk senantiasa menunjukkan sikap maupun tindakan yang baik dalam hal bagaimana berpakean yang sopan dan pantas di lingkungan akademik, sehingga diharapkan dapat menjadi panutan bagi mahasiswa untuk selalu mencontoh.

Sebagaimana Guntur, Soepomo, (2002) menyatakan bahwa, "profesionalisme ini merupakan elemen dan motivasi yang berkontribusi terhadap kinerja tugas yang tinggi'. Karena seorang dosen yang profesional diharapkan memiliki kinerja yang baik yang dapat memuaskan semua pihak yang berkepentingannya didalamnya (stakeholders), yakni mahasiswa itu sendiri, orang tua, dan masyarakat luas. Selain itu kinerja dosen yang baik akan meningkatkan pengembangan dirinya sendiri. Hal tersebut juga dipertegas oleh Badan Penelitian dan Pengembangan Pusat Kurikulum (2010: 15) menyebutkan bahwa, Perencanaan dan pelaksanaan pendidikan karakter bangsa dilakukan oleh kepala kampus, dosen, tenaga pendidik dan diterapkan ke dalam kurikulum melalui; 1) Program Pengembangan Diri, 2) Kegiatan Rutin Kampus, 3) Kegiatan Spontan, 4) Ketaladanan, dan 4) Pengkondisian.

Jelaslah kiranya bahwa hasil temuan penelitian ini sejalan dengan hasil penelitian Bali (2013:5) yang menyatakan bahwa dosen yang menyadari tugas dan kewajibannya harus memiliki karakter sebagai berikut yakni; 1) Memliki 
komitmen yakni, seorang dosen mempunyai tekad yang kuat dalam melaksanakan tugas dan tanggungjawabnya sebagai seorang pendidik, doesen memiliki komitmen yang tinggiakan memiliki ketajaman visi, rasa memiliki dan bertanggungjawan terhadap tugas dan panggilan yang diembannya sebagai pendidik, 2) dosen harus memiliki komptensi yakni, seorang dosen dianggap kompeten jika mampu melaksanakan pembelajaran, dan memecahkan berbagai masalah guna mencapai tujuan pendidikan, 3) dosen harus memiliki semangat kerja keras yakni, sebagao seorang dosen kerja keras merupakan keharusan terutama dalam melaksanakan tugas-tugsanya, khususnya dalam internalisasi pendidikan karakter bagi para mahasiswa, 4) Konsisten yakni, sikap konsisten pada seorang dosen menjadi tanda bahwa dosesn telah menjiwai dan melaksanakan profesinya, konsistensi seorang dosen dapat terlihat dalam katakata dan juga tindakannya, 5) memiliki jiwa sederhana yakni, kesederhanaan seorang dosen dapat dilihat dosen mampu mengaktualisasikan sesuatu secara efektif dan efisien, 6) kemampuan berinteraksi yakni, Seorang dosen juga dituntut memiliki kemampuan berinteraksi secara dinamis dengan para mahasiswa secara emosional dalam mencapai tujuan pembelajaran, 7) Menjaga diri dan kehormatan yakni, seorang dosen yang profesional tidak akan terpengaruhi segala macam tawaran seperti kenaikan gaji, pangkat, kedudukan, ataupun iming-iming materi, 8) dan seorang dosen bisa menjadi Teladan bagi Mahasiswanya, yakni, dosen yang dapat menjadi teladan adalah dosen yang bukan hanya menjaga wibawa atau image saja, namun keteladanan dosen dapat terpancar dari perilaku, tutur kata, sikap, dan perbuatan merupakan sebuah komunikasi yang efektif dalam pendidikan karakter.

Dengan demikian jika seorang dosen senantiasa menyadari tugas dan kewajibabnya sebagai pengajar dan tenaga pendidik yang selalu memperhatikan prinsip-prinsip yang disebutkan Bali (2013:5) di atas, niscaya dosen dapat menjalankan tugasnya dengan baik dalam meningkatkan karakter mandiri kepada mahasiswanya. Dan jika elemen-elemen tersebut tertanamkan dalam budaya belajar di kampus niscaya akan terwujud karakter kampus tempat peserta didik 
saling berinteraksi di lingkungan Prodi PPKn yang memiliki karakter tangguh dan unggul.

\section{B. Peran Dosen dalam Memberikan Kontribusi untuk Mengembangkan Karakter Mandiri Mahasiswa}

Pendidikan karakter membutuhkan perang seorang pendidik dan merupakan tanggungjawab semua elemen. Secara simbolis kalimat tersebut mengambarkan bahwa tugas mengembangkan karakter mandiri kepada peserta didik bukanlah sebuah perkejaan yang ringan.

Berdasarkan data observasi, khususnya di lingkungan Prodi PPKn, masih ditemui sikap mahasiswa yang kurang mandiri sehingga kurangnya rasa tanggungjawab terhadap tugasnya sebagai mahasiswa. Masih ditemui mahasiswa di Prodi PPKn yang tidak tepat waktu dalam menyelesaikan studynya, mahasiswa yang memperoleh nilai IPK (indeks prestasi komulatif) di bawah rata-rata, tidak lulus di mata kuliah prasyarat, dan lain sebagainya. Hal tesebut sudah tentu dapat menghambat proses perkuliahan sehingga mahasiswa tidak dapat lulus tepat waktu. Untuk memotivasi fenomena-fenomena tersebut kita perlu mencermati pepatah yang berbunyi; "Belajarlah sampai ke liang lahat". Dapat diasumsikan bahwa belajar membentuk karakter yang mandiri dan bertanggungjawab tidak hanya sebatas pada sekolah saja, namun masih harus berkelanjutan.

Untuk itu dalam upaya membantu mahasiswa agar dapat menyelesaikan studynya tepat waktu dengan hasil yang memuaskan, sangat diharapkan dalam hal ini peran dosen Prodi PPKn untuk membimbing mahasiswa agar mahasiswa terbiasa untuk mandiri dalam menyelesaikan semua tugas-tugas yang diberikan oleh dosen sehingga mahasiswa dapat menyelesaikan studynya secepat dan seefesien mungkin sesuai dengan kondisi dan potensi individual mahasiswa.

Berdasarkan temuan di lapangan bahwa peran dosen di lingkungan Prodi PPKn dalam memberikan kontribusi untuk mengembangkan karakter mandiri mahasiswa sudah tergambar dalam bentuk yakni, dosen di lingkungan Prodi PPKn sudah memberikan arahan, dan pembimbingan kepada mahasiswa seoptimal mungkin. Dosen beranggapan bahwa peran mereka dalam memberikan arahan dan 
bimbingan merupakan sebuah pelayanan, pengayoman agar mahasiswa memiliki karakter yang ; (1) dapat memahami kemampuan potensial yang dimiliki dirinya dan dapat memanfaatkan potensi itu sebaik-baiknya dalam mengikuti proses perkuliahan, sehingga diharapkan mahasiswa lebih percaya diri dalam menyelesaikan tugas-tugas perkuliahannya, (2) mahasiswa dapat dengan mudah memahami kendala dan kesulitan yang dihadapinya dan mahasiswa dapat dengan segara mampu memecahkan atau mengatasi secara tepat sehingga diharapkan mahasiswa memiliki karakter yang bukan hanya mandiri tetapi berani dalam menghadapi kendala, (3) menyadari bahwa memiliki karakter mandiri dapat menumbuhkan sikap tanggungjawab terhadap dirinya sendiri, sehingga budaya mencontek, maupun budaya copy paste yang mengarahkan pada perbuatan curang terhadap tugas-tugas yang diberikan dosen PPKn dapat diselesaikan dengan mudah dengan tetap menjujung tinggi nilai kejujuran.

Selanjutnya, berdasarkan hasil wawancara dengan beberapa dosen dan beberapa mahasiswa di lingkungan Prodi PPKn ditemukan juga fakta bahwa, dosen di lingkungan Prodi PPKn juga sering memberikan siraman rohani berupa memberikan nasehat yang tegas kepada mahasiswa yang dimbimbingnya, agar perbuatan-perbuatan tercela seperti mencopy pasta tugas, menyotek, melalaikan tugas yang diberikan dosen dalam proses perkuliahan tidak dilakukan. Meskipun demikian beberapa sumber dosen mengungapkan bahwa, kadang kala masih ada mahasiswa yang tidak mengindahkan, tidak mendengarkan bimbingan maupun nasehat dari dosen sehingga mereka mengalami kemunduran dari prestasi akademik.

Melihat beberapa temuan-temuan di lapangan yang sudah dipaparkan, dapat disimpulkan sementara bahwa, peran dosen dalam memberikan kontribusi untuk mengembangkan karakter mandiri mahasiswa, dosen sudah memberikan kontribusi yang cukup besar pada proses pengembangan karakter mandiri mahasiswa di lingkungan Prodi PPKn. Hal tersebut tergambar dari beberapa point yang berkaitan dengan peran dosen yakni; (1) dosen PPKn memberikan nasehat kepada mahasiswa yang sedang dibimbingnya, (2) turut membantu mahasiswa untuk lebih percaya diri dalam memecahkan persoalannya sendiri, (3) dosen tidak 
segan-segan memberikan sanksi kepada mahasiswa yang kedapatan melanggar maupun melakukan perbuatan tercela dalam proses perkulaiahan, dan (4) dosen di lingkungan Prodi PPKn berupaya selalu menjaga kerjasama dengan dosen yang lain dengan meneruskan permasalahan mahasiswa yang bukan wewenangnya kepada dosen yang lebih berwenang untuk menaangani masalah tersebut.

Dengan demikian, dapat diasumsikan bahwa dosen yang berperan aktif dalam mengembangkan karakter mandiri mahasiswa adalah dosen yang memiliki kemampuan atau kompetensi berupa kapasitas berupa kemampuan bersikap, berfikir, dan bertindak tanduk secara mantap sebagai perwujudan dari pengetahuan, sikap dan keterampilan yang dimiliki. Misalnya, seorang dosen juga harus ditutut untuk capak dalam mengelola proses perkuliahan agar suasana komunikatif yang edukatif antara dosen dan peserta didik yang mencakup segi kognitif, afektif, dan psikomotorik, sebagai bentuk dari upaya memperlajari sesuatu berdasarkan perencanaan sampai dengan tahap evaluasi dan tindak lanjut agar tercapai rujuan pengajaran (Subroto, 2002).

Sebagaimana hal tersebut tertuang dalam PP No, 19 Tahun 2015 tentang Standar Nasional Pendidikan dan UU No. 14 Tahun 2005 tentang Guru dan Dosen yang meliputi :

a. Kemampuan pedagogik adalah kemampuan mengelola pembelajaran peserta didik yang meliputi kemampuan merancang, mengelola, dan menilai pembelajaran:

(1) Mampu memahami karakteristik peserta didik

(2) Menerapkan teori belajar, teori pembelajaran yang relevan dengan peserta didik dan sesuai dengan karakteristik mata pelajaran yang dia punya

(3) Mempu mengelola pembelajaran yang sesuai dengan karakteristik peserta didik.

(4) Mampu mengelola pembelajaran yang sesuai dengan karakteristik peserta didik untuk berpartisipasi aktif, serta memberikan ruang yang cukup bagi prakarsa, kreativitas, dan kemandirian sesuai dengan bakat, minat dan perkembangan fisik serta psikologi peserta didik. 
b. Kemampuan keperibadian adalah kepribadian yang mantap, stabil dewasa, atif, dan bijakasana, berwibawa, menjadi teladan bagi peserta didik secara berkelanjutan:

(1) Mampu bertindak secara konsisten yang sesuai dengan norma agama, hukum, sosial, dan kebudayaan nasional Indonesia

(2) Mampu menampilkan diri sebagai peribadi yang mantap, stabil, dewasa, arif, berwibawa, dan berakhlak mulia.

(3) Mempunyai rasa bangga menjadi dosen, dapat bekerja mandiri, mempunyai etos kerja, rasa percaya diri, dan tanggungjawab yang tinggi.

(4) Mampu bersikap dan berprilaku yang disegani.

(5) Mampu menjadi teladan bagi peserta didik dan masyarakat.

(6) Mempunyai kejujuran.

(7) Mampu menjunjung tinggi kode etik profesi dosen.

c. Kemampuan sosial, adalah kemampuan dosen yang meliputi :

(1) Berkomunikasi lisan, tulisan dan atau isyarat

(2) Mengunakan teknologi komunikasi dan informasi secara fungsional

(3) Bergaul secara efektif dengan peserta didik, sesame pendidik, tenaga kependidikan, orang tua/wali peserta didik dan bergaul secara santun dengan masyarakat sekitar.

d. Kemampuan profesioal ada yang meliputi:

(1) Penguasaan materi pembelajaran secara luas dan mendalam

(2) Kemampuan merancang, melaksanakn, dan menyusun laporan penelitian

(3) Kemampuan mengembangkan dan menyebarluaskan inovasi dalam bidang ilmu pengetahuan, teknologi dan/atau senin dan

(4) Kemampuan merancang, melaksanakan dan menilai pengabdian kepada mayarakat.

Dari beberapa kemampuan dosen yang diuraikan diatas merupakan profil kemampuan dasar yang wajib dimiliki seorang dosen. Kamampuan tersebut harus dikembangkan berdasarkan analisis tugas-tugas yang dilaksanakan oleh dosen. Oleh karena itu kemampuan dosen tersebut secara prasional akan mencerminkan fungsi dan peranan dalam membelajarkan anak didik. Melalui pengembangan 
kompetensi pfofesi diusahakan agar penguasaan akademis cepat terpadu secara serasu dengan kemampuan mengajar (Subroto, 2002: 179).

\section{SIMPULAN}

Berdasarkan hasil dan pembahasan penelitian secara umum dapat disimpukan bahwa, peran dosen PPKn dalam mengembangkan karakter mandiri pada mahasiswa dapat disimpulkan secara umum bahwa, dosen seoptimal mungkin dalam berupaya mengembangkan karakter mandiri mahasiswa dengan berbagai macam cara yakni; dosen PPKn berperan sebagai pendidik, sebagai pembimbing, dosen berperan sebagai penasehat bagi mahasiswa, dosen berperan sebagai pembangkit kreativitas dan tanggungjawab kepada mahasiswa, dosen juga berperan sebagai pemberi teladan bagi mahasiwa, meskipun pada kenyataan pengembangan karakter mandiri mahasiswa PPKn belum tampak nyata hasilnya. Simpulan secara khusus dapat di lihat sebagai berikut:

1. Dosen menyadari tugasnya dan meningkatkan kemampuan dalam mengembangkan karakter mandiri kepada mahasiswa yakni;

a. Dosen yang ada di lingkungan Prodi PPKn sudah memahami tugasnya sebagai tenaga pengajar dan memahami fungsi pokok sebagai pendidik yang baik, dan dosen PPKn sudah terlihat cakap dalam menyampaikan ilmu pengetahuan, serta mampu dalam memberikan pemahaman kepada mahasiswa bawah pentingnya untuk mengembangkan kemandirian diri dalam menjalani proses perkuliahan.

b. Dosen juga cakap dalam mengambil keputusan berupa teguran dan hukumna secara mandiri bagi mahasiswa yang kedapatan menjiplak tugas, dan tidak aktif selama proses perkuliahan. Terlihat dedikasi para dosen yang ada di lingkungan Prodi PPKn terhadap profesinya mencerminkan pada pengabdian secara optimal dengan menggunakan pengetahuan dan kecakapan yang dimilikinya. Meskipun ada beberapa dosen yang kadang mengabaikan pelanggaran-pelanggaran yang diperbuat oleh mahasiswa, namun hal tersebut tidak terlalu mempengaruhi para dosen yang lain untuk lebih mengembangkan karakter mandiri kepada mahasiswa, contohnya; dosen berperan dalam 
memberikan suri teladan dalam bentuk dosen senantiasa menunjukkan sikap maupun tindakan yang baik yakni, berbusana sopan sesuai dengan norma dan etika yang berlaku, sehingga diharapkan dapat menjadi panutan bagi mahasiswa untuk mencotohnya

2. Peran dosen dalam memberikan kontribusi untuk mengembangkan karakter mandiri mahasiswa yakni:

a. Peran dosen dalam memberikan kontribusi dalam mengembangkan karakter mandiri mahasiswa cukup besar pada proses pengembangan karakter mandiri mahasiswa di lingkungan Prodi PPKn. Hal tersebut tergambar beberapa point yang berkaitan dengan peran dosen yakni; (1) dosen PPKn memberikan nasehat kepada mahasiswa yang sedang dibimbingnya, (2) turut membantu mahasiswa untuk lebih percaya diri dalam memecahkan persoalannya sendiri, (3) dosen tidka segan-segan memberikan sanksi kepada mahasiswa yang kedapatan melanggar maupun melakukan perbuatan tercela dalam proses perkuliahan, dan (4) dosen di lingkungan PPKn berupaya selalu menjaga kerjasama dengan dosen yang lain dengan meneruskan permasalahan mahasiswa yang bukan wewenangnya kepada dosen yang lebih berwenang untuk menangani masalah tersebut.

b. Mencermati hal tersebut dapatdisimpulkan bahwa dosen yang berperan efektif dalam mengembangkan karakter mandiri mahasiswanya adalah dosen yang memiliki kemampuan atau kompetensi berupa kapasitas berupa kemampuan bersikap, berfikir, dan bertindak secara mantap sebagai perwujudan dari pengetahuan, sikap dan keterampilan yang dimiliki.

\section{DAFTAR PUSTAKA}

Bali. M.M. (2013). Peran Dosen dalam Mengembangkan Karakter Mahasiswa. Humaniora Vol.4 No.2 Oktober 2013. ISSN. 800-810. [di acces 28Februari-2018]

Guntur, dan Soepomo. (2002). Analisis Pengaruh Pengalaman Terhadap Profesionalisme dan Analisis Pengaruh Profesionalisme Terhadap Hasil Belajar Kerja (Outcome). Jurnal Maksi. Vol. 1. (Agustus): 1-17

Nawawi, H. (2007). Metode Penelitian Bidang Sosial. Yogyakarta: Gadjah Media University Press. 
PP No, 19 Tahun 2015 tentang Standar Nasional Pendidikan dan UU No. 14 Tahun 2005 tentang Guru dan Dosen.

Subroto. S. (2002). Proses Belajar di Sekolah: Jakarta. Rineka Cipta.

Sukmadinata, (2006) Metode Penelitian Pendidikan. Bandung: Remaja Rosdakarya.

Sugiyono. (2011). Metode Penelitian Kuantitatif Kualitatif dan R\&D. Bandung: Alfabeta.

Undang-undang No. 20 (2003). Sistem Pendidikan Nasional (Sisdiknas). Yogyakarta: Media Wacana Press.

Wibowo, A. (2013). Pendidikan Karakter di Perguruan Tinggi Membangun

Karakter Ideal Mahasiswa di Perguruan Tinggi. Yogyakarta: Pustaka Pelajar. 